\title{
A Suggested Module for Risk Framework of Water Control Construction Projects using Qualitative and Quantitative Techniques
}

\author{
Omar Mohamed, Mohamed Nour, Iman Elazizy, Mona Hagras
}

\begin{abstract}
Managing risk is an integral part of sound management and risk management helps to achieve projects objectives. Although the process of risk management is standardized to a great extent, risk control strategies depend on project circumstances and feature. One of the essential humanity's challenges in the future, is surely ensuring water needs. Equitable and sustainable management of water resources is a major global challenge, and supply of clean fresh water is decreasing around all nations. Egypt is one of the countries hardest affected by climate change. Also challenges include population growth, increase in food demand and Lack of water and energy Leads to let managing risk for construction of water control structures projects on water streams in Egypt becomes more challenging and essential than ever before. Moreover, this study aims to show the effect of risk on cost and time targets for water control structure projects in Egypt .This study mainly identify a list of significant risk factors effecting on cost and time for these type of projects in Egypt through studying pervious publishing for risk management in construction projects and a questionnaire survey, then conducting a qualitative analysis using a Severity and Probability matrix (S/P matrix) techniques to assess the influence of risk factors and to isolate critical risk factors for a quantitative analysis. Finally, conducting a quantitative analysis by mean of Analytical Hierarchy Process (AHP) to determine the cost and time contingency, $s$ the conclusion of this study shows that the cost contingency needed to account for the different critical risk factors is to increase the estimated cost by $12.35 \%$ on the total estimated budget of the project. In addition that the time contingency needed to consider for different critical risk factors is to increase the scheduled time by $11.25 \%$ over the total originally scheduled of the project.
\end{abstract}

Keywords: risk, risk management, construction projects, water control structure projects in Egypt.

Revised Manuscript Received on February 05, 2020.

* Correspondence Author

Omar Mohamed*, Ph.D. Student of Irrigation and Hydraulics Engineering Department / Faculty of Engineering - Ain Shams University, Cairo, Egypt. Email: omar_mohamed@gasco.com.eg

Mohamed Nour, Professor of Irrigation and Hydraulics Engineering

Department / Faculty of Engineering - Ain Shams University, Cairo, Egypt. Email: mhmdour2@gmail.com

Iman Elazizy, Professor of Irrigation and Hydraulics Engineering Department / Faculty of Engineering - Ain Shams University, Cairo, Egypt. Email: iman.elazizy@gmail.com

Mona hagras, Associated Professor of Irrigation and Hydraulics Department /Faculty of Engineering - Ain Shams University, Cairo, Egypt. Email: mona_hagras@eng.asu.edu.eg

(C) The Authors. Published by Blue Eyes Intelligence Engineering and Sciences Publication (BEIESP). This is an open access article under the CC BY-NC-ND license (http://creativecommons.org/licenses/by-nc-nd/4.0/)

\section{INTRODUCTION}

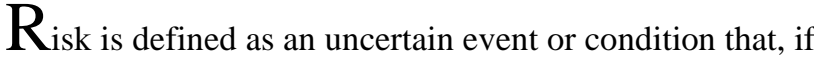
it occurs, has a positive or negative effect on a projects objectives / deliverables due to limited knowledge of the projects consequences versus deliverables / objectives [7]. Projects are exposed to both internal risks such as financial, design, contractual, construction and operational risks, also external risks such as force majeure, bad weather conditions, and legalization problems. All the risks may influence the cost, time or quality of the projects in positive or negative ways [4]. Risk management is an important and vital part of the decision-making process in projects and widely accepted as an important tool in the management of complicated construction projects with interacted activities [10]. There are a lot of risks with multiple and complex manners found in construction industry, because of variety of elements for enterprise environmental factors (EEF) of these projects. The application of risk management used in solving problems that construction projects suffer from it in the past, as to create an alternative ways for proper functioning in execution of projects [5].

Project risk management (PRM) includes the processes of conducting risk management planning, identification, analysis, response planning, response implementation, and monitoring risk on a project in order to optimize the chances of project success and to achieve the project deliverables. According to the Project Management Institute (PMI) project risk management is one of the nine most critical parts of project management to achieve a successful commissioning and start-up phase. This indicates a strong relationship between managing risks and projects success [6].

In (figure1), in construction industry, (PRM) related to Build-Operate-Transfer (BOT) projects should be considered depending on the impact of (EEF) and the organizational system.

\section{A. Previous studies in risk management construction projects}

Saeed (2018) [8] discus the cost and time risk management in construction projects stating that business risk in general is the probability that an actual return of an investment will be less than the expected return. This research is aimed to reduce the influence of business risk in construction projects, by an accurate identifying and evaluating risk through (PRM) cycle. 
Pooworakulchai (2018) discus applied (PRM) in construction industry stating that risk management is applied to many organizations. The Author stated that there are three important things for the applying risk management process which are "Manpower, project data and continuous learning".

Sharma (2011) [9] aims to show a risk management framework for a construction projects and demonstrate its application in an ongoing construction project in Amaravati, Maharashtra, India. As through (EEF) the various risk factors encountered in construction projects and various risk management methods already in use were identified and then a framework was developed which combines the (AHP) and risk map methods.

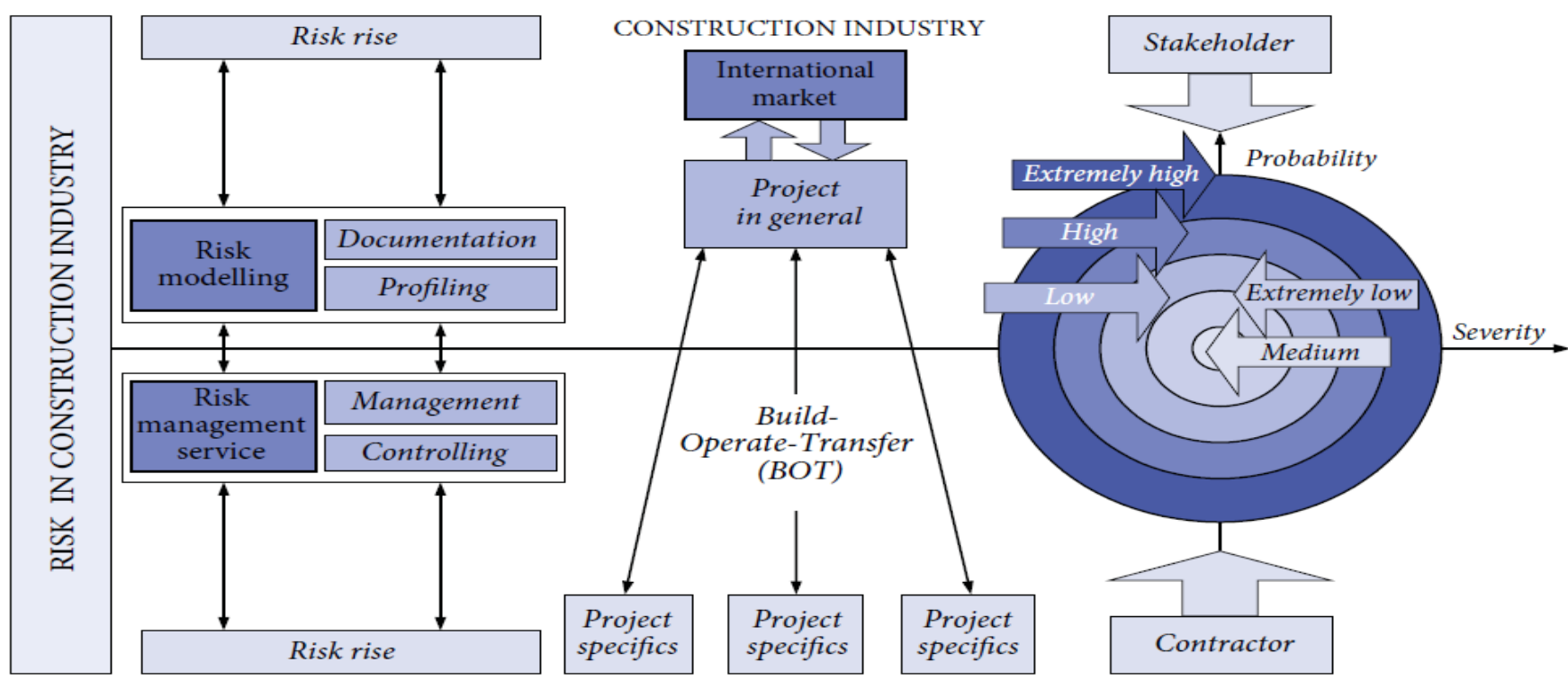

Fig .1. Risk Model in BOT construction projects [3].

\section{B. Risk management related to water control structures in Egypt}

Water Scarcity in Egypt: Egypt is a part of the Mediterranean basin is characterized by a very complex hydrological system, as its rainfall intensity is low where the capital Cairo average rain fall intensity is $30 \mathrm{~mm} /$ year and it almost depend on the Nile river flow as the main source of water. The growth of the Egyptian population and tight economic situation in Egypt leads to an increase in the demand of water and the overall water allocation priority where basically goes to drinking water, industry and whatever is remaining will be available for agriculture and nature. Because the agricultural sector uses more than $80 \%$ of available water due to high water losses in this sector [2]. Water scarcity began in Egypt from almost at the beginning of Year 2000.

Limitation of study for the risk management related to water control structures projects in Egypt: There is a large number of hydraulic water control structures in the Nile valley and in the Nile Delta, which play an important role in controlling, distribution and allocation of water, but mostly these structures are in different stages of degradation. The main problems with these structures include hydraulic inefficiency resulting from leakage and dysfunctional of gate operating. Also these structures suffer from structural instability resulting from erosion for its foundation, differential settlement caused by high traffic loads which lead the necessity of re-habitation and construct a new water control structures on the water streams and channels in Egypt. The limitation of this study is to conduct a total framework for risk management process in the construction of water control structures in Egypt, which are classified as follows:
- Head regulators at the off-takes of canals and drains.

- Intermediate regulators within water streams

- Hydraulic structures located within irrigation canals and drains such as box and pipe culverts

\section{PROBLEM STATEMENT}

Most of the owner project managers in Egypt still take their decisions based on their intuitions, judgment, and experience rather than systematic risk management process [11]. This leads to not achieve cost target and finish the project upon schedule because of this randomly process in taking decisions for any construction project [1].

There are a unique and special risks related to water control construction projects such as "Variation in cost of material and equipment" and "Environmental incompatibility" and "Geotechnical issues and soil analysis troubles" are considered as special risks factors effecting on the cost and time targets for these projects in Egypt compared to other conventional construction projects.

The complex characteristics of these construction projects. Also facing of challenges, tight economic situations and a unique enterprise environmental situation in Egypt. This leads the necessity for predicting the project risks and an essential need to improve management performance and use these support techniques. This study shows the perception and attitude of the construction of water control structure projects in Egypt towards risks factors and categories. It is mainly concerned with the allocation of risks, risk importance and their effects on these types of projects. 


\section{RESEARCH METHODOLOGY}

The study methodology accomplished in this research is simply classified in the following chart as follows (figure 2):

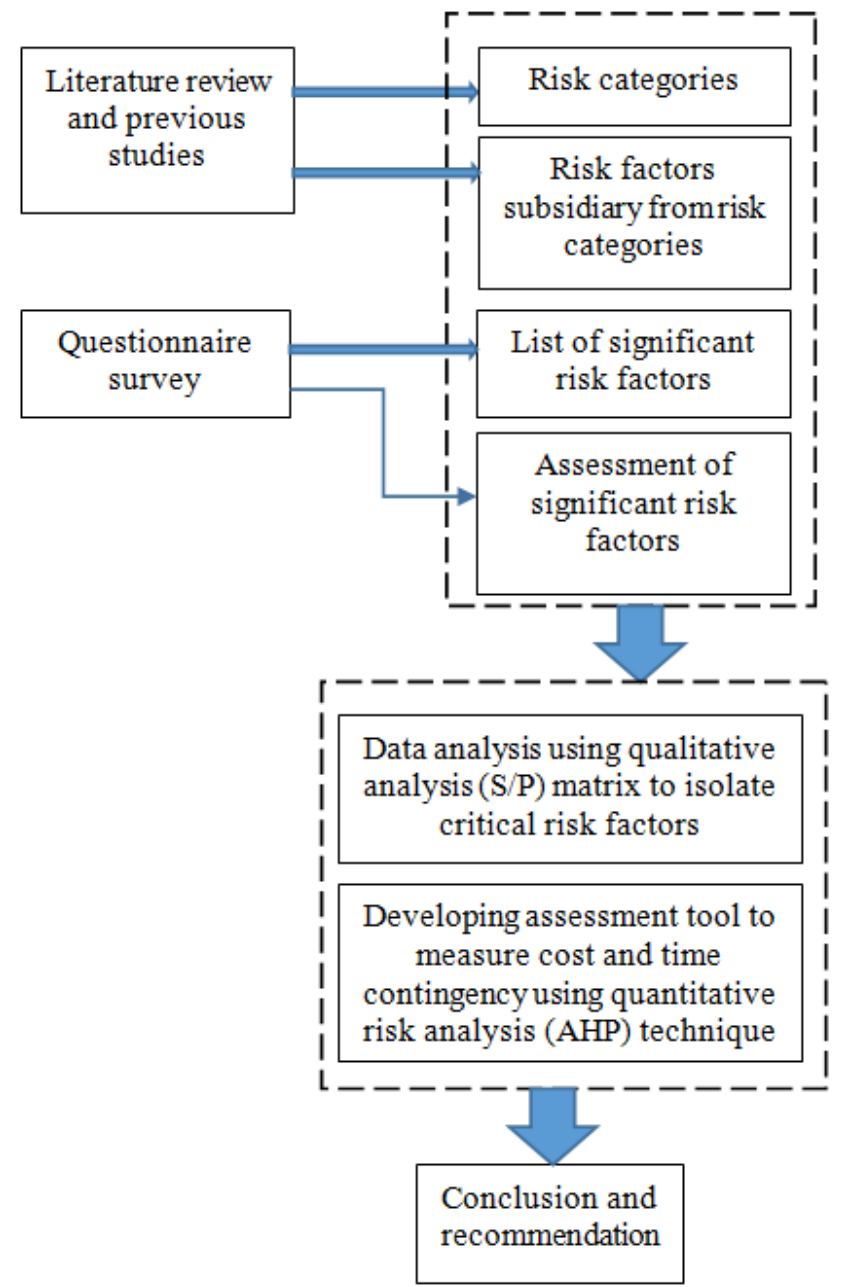

Fig .2. Study methodology flow chart

A. Risk categories should adopted for risk management in the construction of water control structures in Egypt

- Market and financial risks: As market risks are related to the ability to forecast the quantities and prices of outputs and the services provide. And the financial risks is related to risks which involved in attracting investors and moving forward with a project, and includes inability to restructure financial arrangements and unexpected changes of cash flows.

- Supply chain risks: is related to the price and the availability of resources and materials supplied which used in execution of the project.

- Technical risks: include risks associated with unproven or complex technology, changes in technical methodology anticipated during the phases of the project.

- Performance risks: include labor and equipment productivity problems or lower than required. Also may include miss coordination between projects participants.

- External risks: includes those aspects that are external to the project, such as new laws or regulation, bad weather conditions and change foreign policies for projects performed in other countries.

\section{B. List of significant risk factors effecting on cost and} time for construction of water control structures in Egypt

The following table (I) \& table (II) shows the list of significant risk factors effecting on cost and time which is identified by mean of studying related pervious publishing which concerned to risk management in construction projects and a questionnaire survey.

\section{Table- I: List of significant risk factors effecting on cost}

\begin{tabular}{|c|c|c|}
\hline No. & $\begin{array}{c}\text { Risk } \\
\text { categories }\end{array}$ & Risk factors \\
\hline \multirow{3}{*}{1} & \multirow{3}{*}{$\begin{array}{l}\text { Market and } \\
\text { financial risks }\end{array}$} & Increase in rate of inflation than estimated \\
\hline & & Unexpected changes in cash flow \\
\hline & & Restructuring in financial agreements \\
\hline \multirow{4}{*}{2} & \multirow{4}{*}{$\begin{array}{l}\text { Supply chain } \\
\text { risks }\end{array}$} & Variation in the cost of materials \\
\hline & & Variation in the cost of equipment \\
\hline & & Vendors delaying \\
\hline & & $\begin{array}{l}\text { Wrong methodology in material transportation to } \\
\text { site }\end{array}$ \\
\hline \multirow{5}{*}{3} & \multirow{5}{*}{$\begin{array}{l}\text { Technical } \\
\text { risks }\end{array}$} & Over-design of some project items \\
\hline & & Unproven technology to be applicate in site \\
\hline & & $\begin{array}{l}\text { Electro-mechanical design is not compatible with } \\
\text { hydraulic design }\end{array}$ \\
\hline & & Geotechnical issues and soil - analysis troubles \\
\hline & & Wrong estimation of constructability methods \\
\hline \multirow{6}{*}{4} & \multirow{6}{*}{$\begin{array}{l}\text { Performance } \\
\text { risks }\end{array}$} & Labor productivity lower than required \\
\hline & & Equipment productivity lower than required \\
\hline & & $\begin{array}{l}\text { Wrong selection of an equipment type for a } \\
\text { certain task in the project }\end{array}$ \\
\hline & & $\begin{array}{l}\text { Deficiency of human resources for project } \\
\text { participants (poor organization ) }\end{array}$ \\
\hline & & $\begin{array}{l}\text { Not following safety regulation and } \\
\text { Environmental impact not taken into } \\
\text { consideration }\end{array}$ \\
\hline & & Commissioning and start-up problems \\
\hline \multirow{4}{*}{5} & \multirow{4}{*}{$\begin{array}{l}\text { External } \\
\text { risks }\end{array}$} & Bad weather conditions \\
\hline & & $\begin{array}{l}\text { Catastrophic natural phenomena and Force } \\
\text { majeure }\end{array}$ \\
\hline & & Energy and water supply troubles \\
\hline & & Site accessibility troubles \\
\hline
\end{tabular}

The table- I shows (22) significant risk factors subsidiary form risk categories effecting on the cost for construction of water control structures in Egypt, which constructed on water streams and these factors is identified mostly from similar executed projects in the past of ten years which stated by project managers and experts. 
A Suggested Module for Risk Framework of Water Control Construction Projects using Qualitative and Quantitative Techniques

Table- II: List of significant risk factors effecting on time

\begin{tabular}{|c|c|c|}
\hline No. & Risk categories & Risk factors \\
\hline \multirow{3}{*}{1} & \multirow{3}{*}{$\begin{array}{l}\text { Market and } \\
\text { financial risks }\end{array}$} & Change in market demands \\
\hline & & Restructuring in financial agreements \\
\hline & & Change in stockholders orders or views \\
\hline \multirow{6}{*}{2} & \multirow{6}{*}{$\begin{array}{l}\text { Supply chain } \\
\text { risks }\end{array}$} & Un-availability of some materials \\
\hline & & Un-availability of some equipment \\
\hline & & Delaying in vendor supplying \\
\hline & & $\begin{array}{l}\text { Electro-mechanical design is not } \\
\text { compatible with hydraulic design }\end{array}$ \\
\hline & & Geotechnical issues and soil - analysis \\
\hline & & $\begin{array}{l}\text { Wrong estimation of constructability } \\
\text { methods }\end{array}$ \\
\hline \multirow{6}{*}{4} & \multirow{6}{*}{$\begin{array}{l}\text { performance } \\
\text { risks }\end{array}$} & Labor productivity lower than required \\
\hline & & Equipment productivity lower than \\
\hline & & $\begin{array}{l}\text { Wrong bidding items or tendering } \\
\text { documents }\end{array}$ \\
\hline & & Change in managerial philosophy \\
\hline & & $\begin{array}{l}\text { Deficiency of human resources for project } \\
\text { participants (poor organization ) }\end{array}$ \\
\hline & & Commissioning and start-up problems \\
\hline \multirow{3}{*}{5} & \multirow{3}{*}{ External risks } & Bad weather conditions \\
\hline & & $\begin{array}{l}\text { Catastrophic natural phenomena and Force } \\
\text { majeure }\end{array}$ \\
\hline & & Energy and water supply troubles \\
\hline
\end{tabular}

The table-II shows (18) significant risk factors subsidiary form risk categories effecting on the time for construction of water control structures in Egypt, which constructed on water streams and these factors is identified mostly from similar executed projects in the past of ten years which stated by project managers and experts.

\section{QUALITATIVE ANALYSIS OF RISK FACTORS}

In this stage after identification of risk factors, The Analysis of risk factors taking place as the list of significant risk factors shown is assessed by project managers and experts whom fill the questionnaire,

The influence of each significant risk factor calculated by the following Equation:

$$
R \cdot I=\Sigma I / N
$$

Where (R.I.) is the mean value of the influence of risk factor.

(I) influence of risk factor in each questionnaire.

(N) Number of questionnaire.

Qualitative probability and severity risk matrices:

A qualitative risk analysis is conducted, and the aim to do risk analysis is to isolate the critical risk factors and exclude those have a lower impact. Using Probability and Severity risk matrix (S/P matrix).
Table-III: Qualitative risk analysis matrix concerning cost

\begin{tabular}{|c|c|c|c|c|c|}
\hline \multirow[b]{2}{*}{ Severity } & \multicolumn{5}{|c|}{ Increase in budget } \\
\hline & $\begin{array}{c}\text { From } \\
0 \text { to } \\
3 \% \\
(1)\end{array}$ & $\begin{array}{c}\text { From } \\
3 \% \text { to } 10 \% \\
\text { (2) }\end{array}$ & $\begin{array}{c}\text { From } \\
10 \% \text { to } \\
20 \% \\
\\
(3)\end{array}$ & $\begin{array}{c}\text { From } \\
20 \% \text { to } \\
30 \% \\
\\
(4)\end{array}$ & $\begin{array}{c}\text { More } \\
\text { than } \\
30 \% \\
\\
\text { (5) }\end{array}$ \\
\hline $\begin{array}{l}\text { Rare } \\
\text { (1) }\end{array}$ & 1 & 2 & 3 & 4 & 5 \\
\hline $\begin{array}{l}\text { Unlikely } \\
\text { (2) }\end{array}$ & 2 & 4 & 6 & 8 & 10 \\
\hline $\begin{array}{l}\text { Possible } \\
\text { (3) }\end{array}$ & 3 & 6 & 9 & 12 & 15 \\
\hline $\begin{array}{l}\text { Likely } \\
\text { (4) }\end{array}$ & 4 & 8 & 12 & 16 & 20 \\
\hline $\begin{array}{l}\text { Certain } \\
\text { (5) }\end{array}$ & 5 & 10 & 15 & 20 & 25 \\
\hline
\end{tabular}

Table-IV: Qualitative risk analysis matrix concerning time

\begin{tabular}{|c|c|c|c|c|c|}
\hline Severity & \multicolumn{5}{|c|}{ Increase in Duration } \\
\cline { 2 - 6 } & $\begin{array}{c}\text { From } \\
0 \text { to } 3 \%\end{array}$ & $\begin{array}{c}\text { From 3\% } \\
\text { to } 10 \% \\
(2)\end{array}$ & $\begin{array}{c}\text { From } \\
10 \% \text { to } \\
20 \%\end{array}$ & $\begin{array}{c}\text { From } \\
20 \% \text { to } \\
30 \%\end{array}$ & $\begin{array}{c}\text { More } \\
\text { than } \\
30 \%\end{array}$ \\
Probabiliky & $(1)$ & 2 & 3 & 4 & 5 \\
\hline $\begin{array}{c}\text { Rare } \\
(1)\end{array}$ & 1 & $4)$ & $(5)$ \\
\hline $\begin{array}{c}\text { Unlikely } \\
\text { (2) }\end{array}$ & 2 & 4 & 6 & 8 & 10 \\
\hline $\begin{array}{c}\text { Possible } \\
\text { (3) }\end{array}$ & 3 & 6 & 9 & 12 & 15 \\
\hline $\begin{array}{c}\text { Likely } \\
(4)\end{array}$ & 4 & 8 & 12 & 16 & 20 \\
\hline $\begin{array}{c}\text { Certain } \\
\text { (5) }\end{array}$ & 5 & 10 & 15 & 20 & 25 \\
\hline
\end{tabular}

Where: The probability when it is:

- (Rare) it means that the risk may happen from zero to one time all over the project.

- (Unlikely) it means that the risk may happen from two times all over the project.

- (Possible) it means that the risk may happen from three times all over the project.

- (Likely) it means that the risk may happen from four times all over the project.

- (Certain) it means that the risk may happen from five or more times all over the project.

And then from the qualitative matrices the risk is classified into the following according their influences, where:

From (15 to 25) considered as Critical Risks: These should be reduced or eliminated with preventative controls and should be subjected to continuous evaluation and testing. These risks pose maximum risk to the project. 
From (6 to 12) considered as High Risks: These are significant, but are less likely to occur. They need to be monitored on a rotational basis. These risks are second priority after critical risks.

From (3 to 5) considered as Moderate Risks: They are less significant, but have a higher likelihood of occurring. These risks should be monitored to ensure that they are being appropriately managed.

From (1 to 2) considered as Low Risks: They are both unlikely to occur and not significant. They require minimal monitoring.

The completed risk assessment map should give the manager a basis for assessing risks and addressing each one in accordance with its potential impact on business strategy and risk mapping is shown in (figure 3):

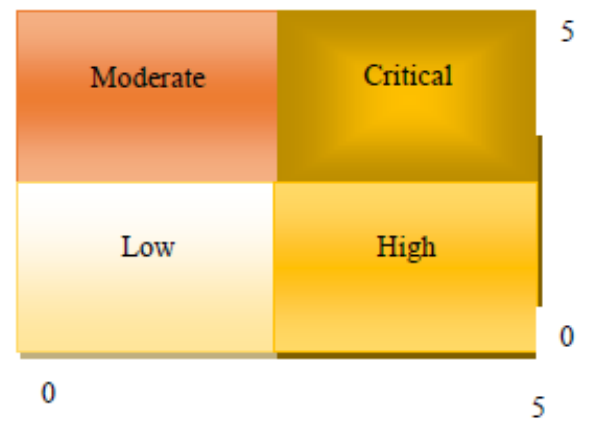

Fig .3 Risk Mapping classified into four parts

\section{QUANTITATIVE ANYLSIS OF CRITICAL RISK FACTORS}

In the qualitative stage the Critical risk factors effecting on cost and time is isolated to enter AHP. The Steps of quantitative analysis adopted in this research using AHP are

- The Critical risk factors are then arranged in a hierarchical tree structure.

- Elements in each level are compared pairwise on a scale of 1-9 with respect to their importance in making the decision under consideration. 1 - Equally preferred, 3 moderately preferred, 5 - strongly preferred, 7 - very strongly preferred and 9 - extremely preferred. If the manager feels that the importance lies in between the given preferences, he can use the middle values of 2, 4, 6 and 8.

- The composite weights of the decision alternatives are then determined by aggregating the weights through the hierarchy. This is done by following path from the top of the hierarchy to each alternative at the lowest level and multiplying the weights along each segment of the path.

And the critical risk factors concerning cost are:

1- Variation in the cost of materials.

2- Variation in the cost of equipment.

3- Geotechnical issues and soil - analysis troubles.

4- Not following safety regulation and Environmental impact not taken into consideration.

5- Restructuring in financial agreements.

6- Labor productivity lower than required.
And the critical risk factors concerning time are:

1- Un-availability of some materials.

2- Un-availability of some equipment.

3- Geotechnical issues and soil - analysis troubles.

4- Force majeure.

5- Commissioning and start-up problems.

6- Labor productivity lower than required.

And the following tables (V) \& (VI) shows the analytical

Table-V: Using (AHP) to measure cost contingency

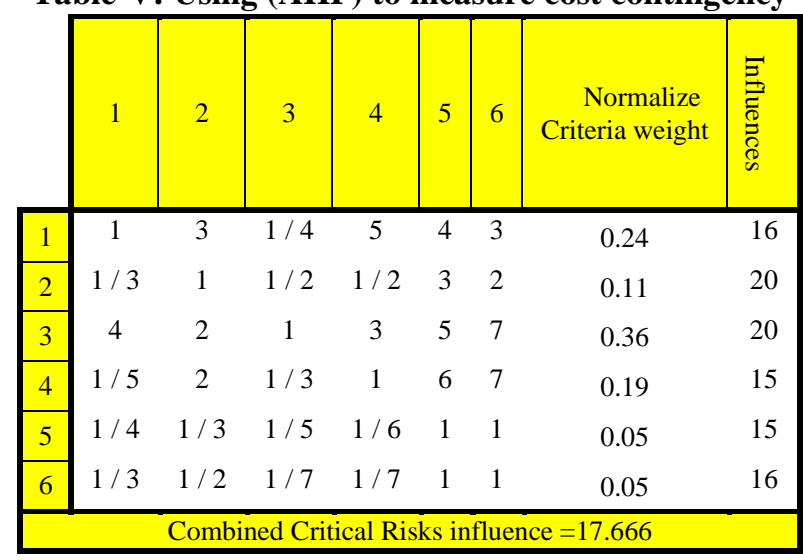

Table-VI: Using (AHP) to measure time contingency

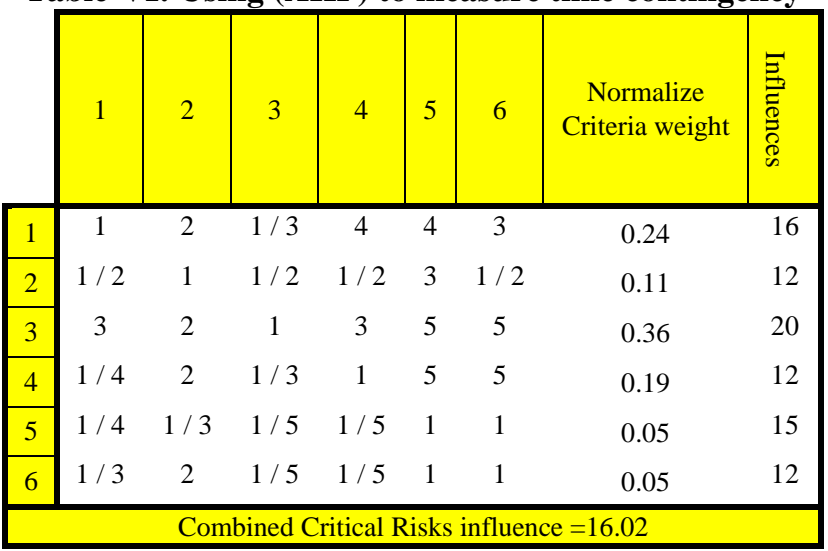

And from the analysis shown the cost and the time contingency is calculated from the qualitative matrices referring to the value of the combined critical risks influences which shows that

1- The cost contingency is $12.35 \%$.

2- The time contingency is $11.25 \%$. 
A Suggested Module for Risk Framework of Water Control Construction Projects using Qualitative and Quantitative Techniques

\section{RESULT OF RESERCH}

The tables shows the final research result

Table -VII: The list of significant risk factors affecting on cost in descending order and the cost contingency

\begin{tabular}{|c|c|c|c|}
\hline No. & Significant risk factors & $\begin{array}{c}\text { Qualitative } \\
\text { analysis }\end{array}$ & $\begin{array}{c}\text { Cost } \\
\text { contingency }\end{array}$ \\
\hline 1 & $\begin{array}{c}\text { Geotechnical issues and soil - } \\
\text { analysis troubles }\end{array}$ & 20 & \multirow{6}{*}{$12.35 \%$} \\
\hline 2 & Variation in the cost of equipment & 20 & \\
\hline 3 & $\begin{array}{c}\text { Labor productivity lower than } \\
\text { required }\end{array}$ & 16 & \\
\hline 4 & Variation in the cost of materials & 16 & \\
\hline 5 & $\begin{array}{c}\text { Restructuring in financial } \\
\text { agreements }\end{array}$ & 15 & \\
\hline 6 & $\begin{array}{l}\text { Not following safety regulation } \\
\text { and Environmental } \\
\text { incompatibility }\end{array}$ & 15 & \\
\hline
\end{tabular}

Table -VIII: The list of significant risk factors affecting on time in descending order and time contingency:

\begin{tabular}{|c|c|c|c|}
\hline No. & Significant risk factors & $\begin{array}{l}\text { Qualitative } \\
\text { analysis }\end{array}$ & $\begin{array}{c}\text { Time } \\
\text { contingency }\end{array}$ \\
\hline 1 & $\begin{array}{l}\text { Geotechnical issues and soil - } \\
\text { analysis troubles }\end{array}$ & 20 & \multirow{6}{*}{$11.25 \%$} \\
\hline 2 & Un-availability of some materials & 16 & \\
\hline 3 & $\begin{array}{l}\text { Commissioning and start-up } \\
\text { problems }\end{array}$ & 15 & \\
\hline 4 & $\begin{array}{c}\text { Labor productivity lower than } \\
\text { required }\end{array}$ & 12 & \\
\hline 5 & $\begin{array}{l}\text { Un-availability of some } \\
\text { equipment }\end{array}$ & 12 & \\
\hline 6 & Force majeure & 12 & \\
\hline
\end{tabular}

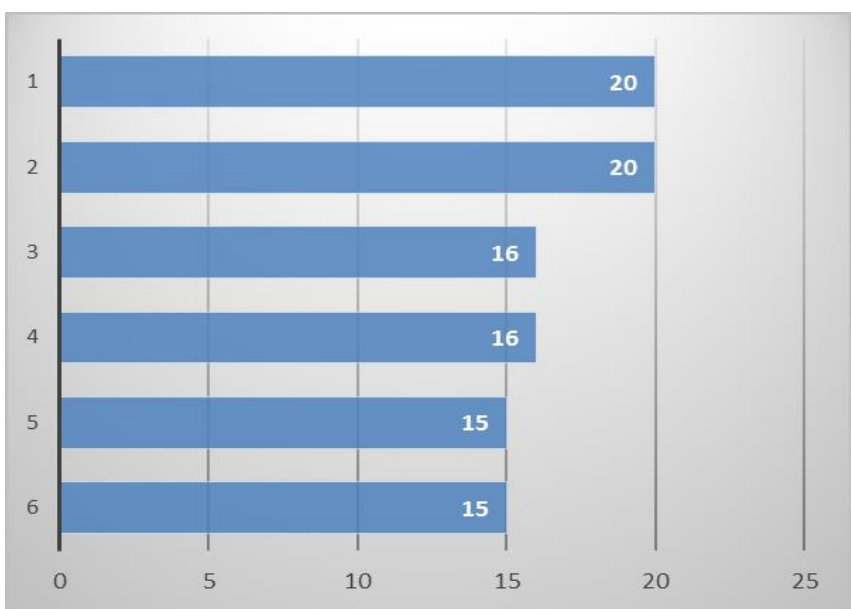

Fig .4. Sensitivity analysis concerning cost

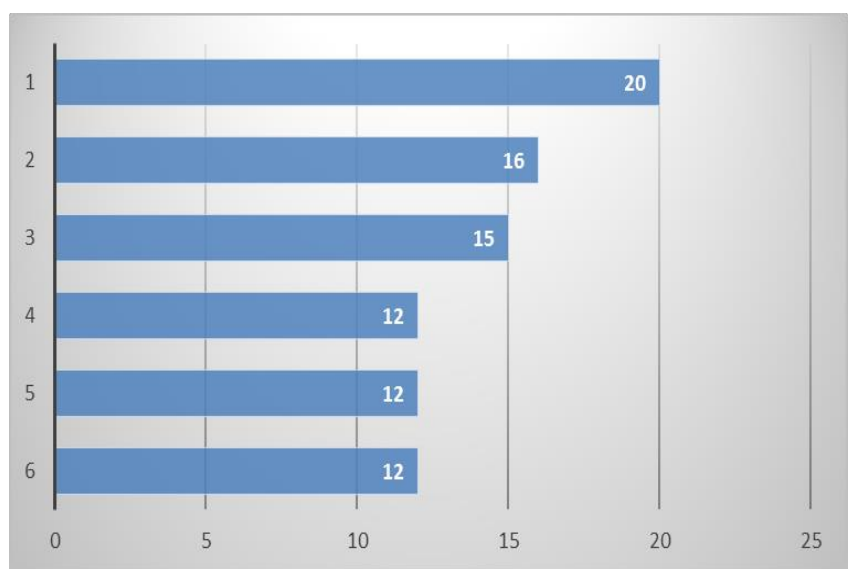

Fig .5. Sensitivity analysis concerning time

\section{CONCLUSION}

$\checkmark$ The risk management process showed in the research should be adopted with the same methodology shown, and to be applied all over the project life cycle for the construction of water control structure projects in Egypt, as taken into consideration the risk factors shown subsidiary from each risk categories, mutually helps in optimizing the cost and the duration of these type of projects, leading to a successful project targets, as not implementing risk management process concerning hazard factors only.

$\checkmark \quad$ The cost contingency needed to account for the different risk factors defined in this research is to increase the estimated cost by $12.35 \%$ on the total estimated budget of the project. The time contingency needed to consider the different risk factors affecting on the project time is to increase the scheduled time by $11.25 \%$ over the total originally scheduled of the project.

\section{REFERENCES}

1. M. Algarhi, "Gas industry in Egypt", Thesis (Ph.D.), American University in Cairo (AUC), 2009, Cairo, Egypt.

2. W. Gunidy, "Egypt is the gift of Nile ", National water research center, Ministry of Water resources and irrigation, 2015, Cairo, Egypt.

3. T. Iqbal, "Risk management in construction projects". (Research gate) Technological and economic development journal, 2015, Freiberg, Germany, Vol. 21 No. 1, pp. 65-78

4. D. Kumar, "Risk management in oil and gas construction projects in Vietnam", Thesis (Ph.D.), International Journal of Energy Sector management, 2007 , Vietnam, Vol. 1 No. 2, pp. 175-194

5. C. Pooworakulchai, "Applied risk management in construction industry: A Review ", (Research gate) International Journal of engineering technologies and management research, Ramkhamhaeng University, 2018, Bangkok, Thailand, Vol.5 (Iss.3), ISSN: 2454-1907.

6. Project Management Institute (PMI). A Guide to the Project management Body of Knowledge (PMBOK Guide), 2007 6thEdition, ANSI/PMI 99-001-2017, Newton Square, Pennsylvania.

7. I. Rashid, "Risk and Risk Management definitions" Lectures in construction management, Faculty of Engineering, Cairo University, 2007, Cairo, Egypt.

8. S. Saeed, "Cost and Time Risk Management in Construction Projects". (Research gate) Tikrit Journal of Engineering Sciences, Kirkuk University, 2018, Kirkuk, Iraq. ISSN: 1813-162X (Print); 2312-7589 (Online), 
9. S. Sharma, "Risk Management in Construction Projects Using Combined Analytic Hierarchy Process and Risk Map Framework". (Research gate) The IUP Journal of Operations Management, Birla Institute of Technology and Science Pilani, 2011, Birla , India Vol. XII, No. 4.

10. Y. Tang, "Risk management in the Chinese construction industry." Journal of construction engineering and management, 2007, Vol. 133, No.12, pp. 944-956.

11. N. Zabaal, "Risk management of pipeline infrastructure projects in Egypt". Thesis (M.Sc.) Faculty of Engineering, Cairo University, 2007, Cairo, Egypt.

\section{AUTHORS PROFILE}

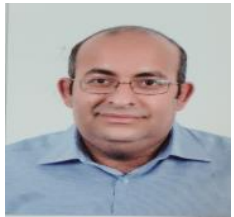

Eng.Omar Mohamed studied Civil Engineering at faculty of Engineering / Ain Shams University from 1999 to 2004. And awarded Master of Science (M.Sc.) for Arab Academy for Science and Technology and Maritime (AAST) at April 2016 with thesis entitled (Risk management in construction of gas plants and gas pipelines in Egypt. I began my Ph.D. research work in Faculty of Engineering / Ain shams University at 2017 and I'm still a Ph.D. student in the topic of (Risk management in the construction of water control structures). I'm still working at in Cairo, Egypt as a civil Engineer. And also I attend a lot of technical conference and sessions as a Technical speaker, and I'm looking forward to attend a conference in Egypt known as EGYPS2020.

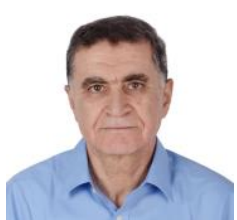

Professor Dr. Mohamed Nour El-Din is a Wate Resources scientist with extensive long experience in applying integrated water resources management and development in arid and semi-arid regions, water supply, rural sanitation, water resources planning, monitoring and evaluation of irrigation projects and drainage systems. The main experience is in Egypt, as well as several assignments in other countries as well through cooperation with consultants and international organizations. The experience is acquired also through his career as a university professor and as a consultant in several water resources and irrigation projects. And mainly the current work is a Professor of hydraulics and irrigation in faculty of Engineering / Ain shams University

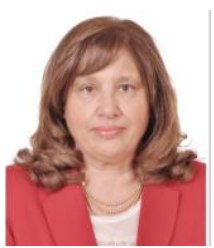

Prof. Dr. Iman Elazizy is a Professor of Hydraulics and water resources working at Faculty of Engineering., Ain Shams University Cairo, Egypt. The research interest is; Water quality modeling, Water recourses management, natural treatment process, wetland, GIS application in water recourses, Open channel hydraulics. Environmental Impact Assessment. Works as consultant for Environmental water project for EEAA Egypt.

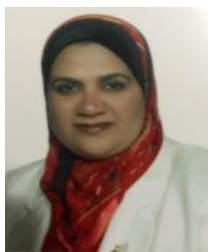

Dr. Mona A. Hagras is Associate Professor of Irrigation\& Hydraulics Department, Faculty of Engineering, Ain Shams University, Cairo, Egypt. She received PhD and MSc from Ain Shams University. She supervised many theses and published many papers in referred national and international journals. She is a reviewer of ASEJ journals. Her area of interest is Water Resources Management, Hydrology, Hydraulics, and Groundwater modeling. 